\title{
SKEMA KANTOR CABANG PEMBANTU SYARIAH \\ DAN UNIT SYARIAH (US) DALAM RANGKA PENGEMBANGAN KANTOR BANK SYARIAH
}

\section{Latar Belakang}

Salah satu kebijakan pengembangan bank Syariah di Indonesia adalah pengembangan jaringan kantor bank Syariah. Pengembangan jaringan kantor bank Syariah diperlukan dalam rangka memenuhi kebutuhan masyarakat terhadap jasa perbankan berdasarkan prinsip Syariah.

Sesuai dengan ketentuan Undang-undang No.10 Tahun 1998, hal-hal yang berkaitan dengan ketentuan perizinan kelembagaan dan kegiatan usaha bank berdasarkan prinsip Syariah dapat ditetapkan secara tersendiri. Ketentuan perizinan yang ada mengatur tatacara: pendirian bank (umum atau BPR) Syariah baru, konversi bank (umum atau BPR) konvensional menjadi bank Syariah, dan pembukaan kantor cabang Syariah oleh bank umum konvensional.

Dalam pelaksanaan sistem pembukaan Kantor Cabang Syariah hingga saat ini belum mendapatkan respon yang menggembirakan dari perbankan konvensional. Dewasa ini baru terdapat 11 KCS di Indonesia masing-masing 9 KCS BNI, 1 KCS Bank IFI, dan 1 KCS Bank Jabar.

Berkaitan dengan mekanisme pembukaan kantor cabang pembantu Syariah dan unit Syariah, dalam penjelasan Pasal 6 huruf $\mathrm{m}$ UU No.10 Tahun 1998 ditentukan sebagai berikut: Bank umum yang melakukan kegiatan usaha secara konvensional dapat juga melakukan kegiatan usaha berdasarkan Prinsip Syariah melalui pendirian kantor cabang Syariah atau kantor cabang pembantu Syariah baru atau pengubahan kantor cabang atau kantor di bawah kantor cabang yang melakukan kegiatan usaha secara konvensional menjadi kantor yang melakukan kegiatan berdasarkan Prinsip Syariah. Dalam rangka persiapan perubahan kantor bank tersebut, kantor cabang atau kantor di bawah kantor cabang yang sebelumnya melakukan kegiatan usaha secara konvensional dapat terlebih dahulu membentuk unit tersendiri yang melaksanakan kegiatan berdasarkan Prinsip Syariah di dalam kantor bank tersebut.

Pembentukan Unit tersendiri tersebut merupakan pelaksanaan konsep "windows" kegiatan usaha bank Syariah yang sudah dilakukan oleh perbankan di Malaysia sejak tahun 1993. Berdasarkan penelitian lapangan diketahui bahwa penerapan windows di Malaysia 
dikenal dengan nama Skim Perbankan Tanpa Faedah (SPTF) mulai dilakukan sejak tahun 1994 dan mendapat tanggapan yang sangat baik dari perbankan konvensional sehingga menunjukkan pertumbuhan yang sangat pesat. Sejak diberlakukannya ketentuan SPTF tersebut hingga akhir Maret 2001 jumlahnya mencapai 2095 kantor. Pertumbuhan kantor SPTF ini memiliki sumbangan yang sangat besar bagi pertumbuhan aset perbankan Syariah terhadap perbankan nasional Malaysia dari sekitar 3\% pada tahun 1998 menjadi 6,8\% pada akhir Maret 2001.

Dengan memperhatikan pengalaman keberhasilan Malaysia dalam penerapan SPTF, maka dalam upaya menarik minat perbankan untuk menyediakan pelayanan bank Syariah perlu dilakukan pengembangan skema kantor bank yang memiliki mekanisme serupa dengan SPTF Malaysia. Mekanisme pengembangan jaringan terutama ditujukan untuk memperluas pelayanan jasa bank Syariah oleh bank umum konvensional. Bank konvensional telah memiliki infrastruktur jaringan kantor yang luas sehingga dapat dimanfaatkan sebagai sarana pengembangan jaringan kantor bank Syariah dengan tetap berpegang kepada prinsip kerjasama usaha yang saling menguntungkan (win win solutions business) serta praktek perbankan yang sehat. Perlu dikemukakan pula bahwa pengembangan jaringan kantor bank Syariah tetap diarahkan pada kerangka pembentukan kantor cabang Syariah penuh (full fledge branch). Pembentukan full fledge branch ini terkait dengan amanat Undang-undang Perbankan tahun 1998 yang menentukan bahwa pembukaan Unit Syariah adalah masa persiapan untuk pendirian kantor cabang Syariah penuh.

Skema Unit Syariah memiliki manfaat dari aspek makro dan mikro. Secara makro Unit Syariah bermanfaat untuk memperluas jaringan pelayanan bank Syariah, sehingga dapat lebih menyentuh sektor riil yang lebih luas dibandingkan KCS. Dari aspek mikro biaya Unit Syariah lebih efisien karena menggunakan sarana kantor yang sudah tersedia, dan pelaksanaannya lebih mudah karena hanya sebagai counter kantor cabang.

Selanjutnya dapat dikemukakan pula bahwa pengkajian ini bertujuan untuk memberikan informasi dan uraian yang jelas dan komprehensif mengenai pengaturan, tatacara pendirian dan aspek pengawasan Unit Syariah agar penyusunan kebijakan Bank Indonesia didasarkan pada hasil pengkajian yang dapat dipertanggung jawabkan (researchbased policy).

\section{Mengamati Pengembangan Bank Syariah dan SPTF di Malaysia}

Pengembangan perbankan Syariah di Malaysia dipengaruhi oleh faktor eksternal dan internal. Dari sisi eksternal, pengembangan perbankan Syariah di Malaysia dilatarbelakangi oleh suksesnya kegiatan usaha bank Islam pertama yaitu Dubai Islamic bank di Uni Emirat Arab (1975) dan Islamic Development Bank di Arab Saudi (1975). Pengaruh 
eksternal lainnya adalah perkembangan yang cepat dari lembaga keuangan Islam di dunia dan upaya dari negara-negara Islam untuk mengubah sistem perbankan konvensional menjadi sistem perbankan Islam. Faktor-faktor eksternal ini mendorong para pakar, pengamat, dan pemerintah di Malaysia untuk menerapkan sistem perbankan Syariah di negaranya. Sedangkan dari sisi internal, terdapat peningkatan permintaan masyarakat muslim Malaysia atas jasa perbankan Islam setelah melihat keberhasilan pengembangan perbankan Islam di negara-negara Timur Tengah. Faktor pendorong internal lain adalah keberhasilan dari program tabung haji dan dukungan aktif pemerintah Malaysia untuk menyediakan sistem perbankan alternatif untuk memenuhi kebutuhan umat muslim. Adanya dukungan faktor eksternal dan intenal tersebut telah mendorong pembentukan Undang-Undang Perbankan Islam Malaysia (Islamic Banking Act 1983) dan berdirinya Bank Islam Malaysia Berhad (BIMB) sebagai bank Islam pertama di Malaysia pada bulan Juli 1983.

Selanjutnya penting juga untuk mengetahui visi Bank Negara Malaysia (BNM) dalam pengembangan bank Syariah. Pada tahun 1990, Gubernur BNM menetapkan visi pengembangan bank Syariah yaitu "untuk mewujudkan sistem perbankan Islam yang beroperasi sejajar dan berdampingan dengan sistem perbankan konvensional. Selanjutnya visi tersebut disempurnakan dalam Islamic Banking Vision Statement 2001 menjadi “untuk membentuk sistem perbankan Islam yang efisien, progresif, dan komprehensif yang memberikan kontribusi terhadap efektifitas dan efisiensi sektor keuangan Malaysia dalam rangka memenuhi kebutuhan perekonomian negara".

Kebijakan pengembangan perbankan nasional Malaysia berdasarkan pada dual banking system dengan alasan bahwa "satu sistem bank Islam tidak dapat mewakili sistem perbakan nasional". Alasan lainnya adalah bahwa dengan adanya dual banking system tersebut maka terdapat kesempatan bagi masyarakat untuk memilih sistem perbankan yang sesuai dengan keyakinan agamanya. Dalam dual banking system ini, pemerintah berkewajiban untuk menyediakan sistem dan produk perbankan alternatif baik Islam maupun konvensional serta mendirikan lembaga keuangan pendukung untuk kedua sistem tersebut. Selain itu, bagi para bankir, sistem perbankan Syariah tersebut menjadi sangat menarik karena produk dan jasa yang disediakan oleh bank Syariah ternyata lebih banyak dan didukung oleh teknologi informasi yang semakin canggih.

Pembentukan skema SPTF bertujuan untuk memperluas dan mempromosikan perbankan Islam secara luas kepada masyarakat dengan mempergunakan infrastruktur perbankan konvensional yang ada. Penerapan SPTF pertama kali tahun 1994 dilakukan dengan proyek percontohan (pilot project) pada tiga bank nasional di Malaysia yaitu Malayan Bank Berhad, Bank Bumiputra Berhad, dan United Malayan Banking Corporation Berhad. Proyek percontohan tersebut berhasil dengan baik dan selanjutnya diterapkan secara luas kepada seluruh perbankan komersial di Malaysia. 
Adapun produk dan jasa yang ditawarkan oleh SPTF dengan contoh RHB Bank adalah sebagai berikut:

\begin{tabular}{|c|c|}
\hline \multicolumn{2}{|c|}{ Lampiran 2. Profil Ringkas RHB } \\
\hline $\begin{array}{l}\text { Modal kerja } \\
\text { Kantor Cabang "windows" IBS } \\
\text { Produk dan jasa BIMB }\end{array}$ & $\begin{array}{l}\text { RM } 32 \text { juta } \\
160 \text { Kantor Cabang } \\
34 \text { Macam produk dan jasa }\end{array}$ \\
\hline $\begin{array}{l}\text { Produk Pembiayaan } \\
\text { - Murabahah } \\
\text { - Bai Bithaman Ajil } \\
\text { - Bai Istisnaa } \\
\text { - Bai Al Dayn } \\
\text { - Ijarah } \\
\text { - House Financing } \\
\text { - Study Financing } \\
\text { - Islamic Overdraft Facility } \\
\text { - Unit Trust Financing } \\
\text { - Other Consumer Financing }\end{array}$ & $\begin{array}{l}\text { Produk-Simpanan: } \\
\text { - Wadiah Current Account } \\
\text { - Wadiah Savings Account } \\
\text { - Wadiah Student Saving Account } \\
\text { - Mudharabah General Investment Account } \\
\text { - Mudharabah Current Account } \\
\text { - Mudharabah Special Investment Account } \\
\text { - Unit Link Mudharabah }\end{array}$ \\
\hline $\begin{array}{l}\text { Produk Pembiayaan Komersial } \\
\text { - Asset/Working Capital/Other Financing } \\
\text { - Islamic Overdraft Facility } \\
\text { Produk Pasar Keuangan Islam } \\
\text { - Islamic Accepted Bills (IAB) } \\
\text { - Islamic Debt Securities (short/long term) } \\
\text { - Cagamas Mudharabah Bonds } \\
\text { - Lending/borrowing } \\
\text { - Negotiable instruments Debt Certificate } \\
\text { (NIDC) }\end{array}$ & $\begin{array}{l}\text { Produk Pembiayaan Perdagangan } \\
\text { - Kafalah Bankers Guarantee } \\
\text { - Wakalah Letter of Credit (WLC) } \\
\text { - Wakalah Inward Bill Collection (WIBC) } \\
\text { - Wakalah Outward Bill Collection (WOBC) } \\
\text { - Kafalah Shipping Guarantee } \\
\text { - Murabahah Working Capital Financing } \\
\text { - } \text { I MWCF) } \\
\text { - Islamic Acceptance Bill (Purchase) } \\
\text { - Islamic Exceptance Bill (Sales) } \\
\text { - Ishipment) } \\
\text { shipmic Export Credit Refinancing (Post- }\end{array}$ \\
\hline Indikator Keuangan & $\begin{array}{l}\text { - Total asset RM 2.575.990.000 } \\
\text { - Total Simpanan RM 1.797.127.000 } \\
\text { - Demand Deposit RM } 374.948 .000 \\
\text { - Saving Deposits RM 144.251.000 } \\
\text { - General Invest Account RM 1.277.928.000 } \\
\text { - Total Pembiayaan RM } 1.155 .049 .000 \\
\text { - Bai Inah RM 532.589.000 } \\
\text { - Bai Bithaman Ajil RM } 331.164 .000 \\
\text { - Ijarah RM 13.399.000 } \\
\text { - Murabahah RM 277.897.000 }\end{array}$ \\
\hline
\end{tabular}

*) Sumber: RHB Islamic Banking Unit 2001 


\section{SPTF dalam struktur organisasi bank}

Letak SPTF dalam struktur organisasi pada dasarnya merupakan bagian dari kantor cabang karena diperlakukan sebagai produk (windows) kantor cabang. Walaupun merupakan produk dari kantor cabang tetapi transaksi harian dan pembukuan dilakukan secara terpisah. Selain itu di kantor pusat bank harus dibentuk Islamic Banking Unit (IBU). IBU mempunyai tugas sebagai berikut:

a. mengurus operasional SPTF termasuk kebijakan dan kegiatan prosedural;

b. penghubung dengan satuan kerja lain di bank dalam rangka kelancaran kerja SPTF;

c. memastikan bahwa seluruh dana disalurkan kepada pembiayaan yang berdasarkan prinsip Syariah;

d. mengatur pelatihan kepada pegawai dalam rangka kelancaran penerapan SPTF;

e. mempersiapkan kompilasi dan pelaporan yang diwajibkan atau diminta oleh bank sentral;

f. memastikan bahwa seluruh petunjuk dan arahan bank sentral terhadap SPTF telah dipatuhi oleh SPTF;

g. melakukan penelitian dan pengembangan di bidang perbankan Syariah;

h. tugas dan peran lainnya yang ditetapkan oleh bank atau bank sentral dari waktu ke waktu.

i. pimpinan IBU adalah pejabat senior, berpengalaman dan sebaiknya seorang muslim.

Dalam aplikasi jaringan kantor Syariah di Indonesia IBU dapat dianalogikan dengan Unit Usaha Syariah (UUS).

\section{Disain Kantor Cabang Pembantu Syariah (KCPS)}

Fungsi dan tugas KCPS dalam skema ini pada dasarnya memiliki fungsi dan tugas yang sama dengan Kantor Cabang Pembantu pada umumnya yaitu sebagai kepanjangan tangan kegiatan usaha dan bertanggungjawab kepada Kantor Cabang. Namun demikian disain KCPS disini memiliki perbedaan karakteristik yang cukup mendasar dengan skema pembukaan kantor cabang pembantu yang telah diatur selama ini yaitu dapat beralamat di kantor cabang atau kantor cabang pembantu konvensional, harus menyediakan modal kerja, serta tenaga kerja yang tidak terlalu banyak. 


\section{Mekanisme Operasional}

Tujuan pembentukan KCPS adalah membentuk jaringan kantor bank Syariah yang murah dan efisien, menjangkau wilayah yang luas, memiliki kredibilitas Syariah yang tinggi, serta mampu menjalankan praktek perbankan yang sehat. Dalam upaya mencapai tujuan tersebut maka berbeda dengan skema kantor cabang pembantu pada umumnya, skema KCPS di disain memiliki karakteristik sebagai berikut:

1. Merupakan kantor cabang pembantu Syariah yang beralamat sama dengan kantor cabang konvensional;

2. Bertanggungjawab terhadap Kantor Cabang Syariah induk yang berlokasi dalam satu wilayah kerja Bank Indonesia;

3. Memiliki ruangan atau counter tersendiri;

4. Memiliki pegawai tersendiri;

5. Kegiatan usaha meliputi kegiatan penghimpunan dana, penyaluran dana, dan jasa perbankan lainnya;

6. Laporan keuangan dan transaksi merupakan bagian dari laporan keuangan dan transaksi Kantor Cabang Syariah induknya;

7. Bukan merupakan satuan kerja transisi sehingga tidak dibatasi jangka waktu tertentu.

Adanya karakteristik berlokasi yang beralamat sama dengan kantor cabang konvensional akan banyak membantu efisiensi biaya operasional dan penyediaan tenaga kerja. Walaupun jumlah pegawai relatif lebih sedikit tetapi KCPS diberi kewenangan yang luas dalam bidang kegiatan usaha yang meliputi penghimpunan dana, penyaluran dana, dan penyediaan jasa perbankan Syariah.

Struktur organisasi KCPS dapat digambarkan sebagai berikut:

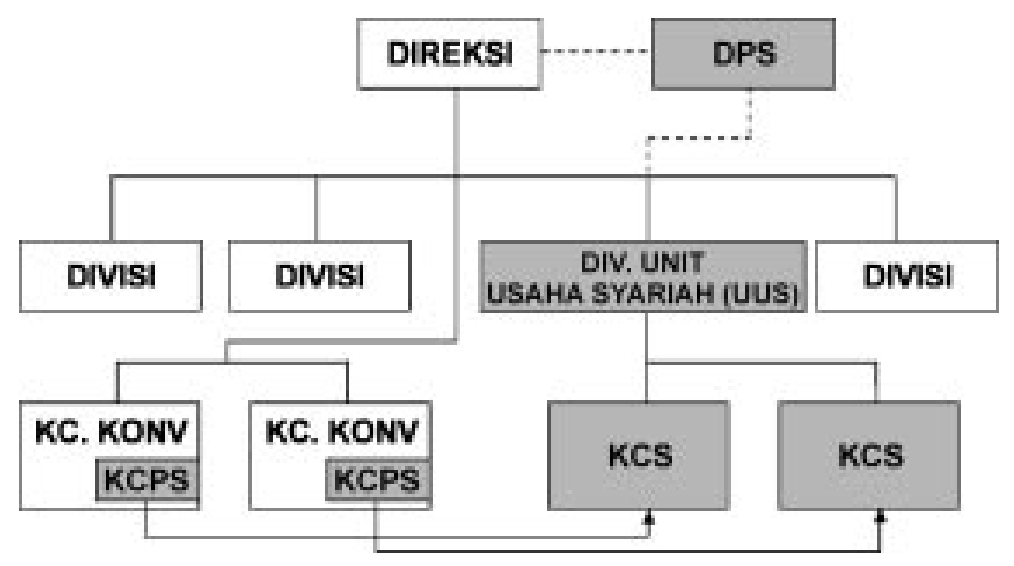




\section{Analisis Pros dan Cons}

Dengan memperhatikan disain KCPS tersebut, maka analisa pros dan cons yang muncul adalah sebagai berikut:

\begin{tabular}{|c|c|c|}
\hline Disain & Pros & Cons \\
\hline $\begin{array}{l}\text { 1. KCPS sebagai counter yang } \\
\text { bertempat di kantor cabang } \\
\text { konvensional. }\end{array}$ & $\begin{array}{l}\text { - Biaya sewa murah sehing- } \\
\text { ga lebih efisien; }\end{array}$ & $\begin{array}{l}\text { - Kemungkinan adanya resistensi } \\
\text { dari KCK sebagai kompetitor; }\end{array}$ \\
\hline $\begin{array}{l}\text { 2. Bertanggungjawab thd } \\
\text { Kantor Cabang Syariah yang } \\
\text { berlokasi dalam satu wila- } \\
\text { yah kerja Bank Indonesia. }\end{array}$ & $\begin{array}{l}\text { - Kredibilitas dari masya- } \\
\text { rakat dalam penerapan } \\
\text { Syariah. }\end{array}$ & $\begin{array}{l}\text { - Adanya ketergantungan de- } \\
\text { ngan KCS induk dalam pelak- } \\
\text { sanaan kegiatan usaha dan } \\
\text { kliring. }\end{array}$ \\
\hline $\begin{array}{l}\text { 3. Memiliki pegawai tersendiri } \\
\text { (sekitar sekurang-kurangnya } \\
3 \text { orang); }\end{array}$ & $\begin{array}{l}\text { - Efisiensi biaya tenaga } \\
\text { kerja; } \\
\text { - Meningkatkan kredibilitas } \\
\text { penerapan Syariah; }\end{array}$ & $\begin{array}{l}\text { - Adanya kemungkinan over } \\
\text { load pekerjaan. }\end{array}$ \\
\hline $\begin{array}{l}\text { 4. Kegiatan usaha meliputi } \\
\text { kegiatan penghimpunan } \\
\text { dana (funding), penyaluran } \\
\text { dana (financing) dan jasa } \\
\text { perbankan lainnya (service). }\end{array}$ & $\begin{array}{l}\text { - Menyediakan pelayanan } \\
\text { perbankan Syariah yang } \\
\text { lengkap. } \\
\text { - Mendukung percepatan } \\
\text { penyelenggaraan sistem } \\
\text { perbankan Syariah yang } \\
\text { luas. }\end{array}$ & $\begin{array}{l}\text { - Ekstra pengawasan internal } \\
\text { KCS; } \\
\text { - Ekstra pengawasan bank } \\
\text { sentral; }\end{array}$ \\
\hline $\begin{array}{l}\text { 5. Laporan keuangan dan } \\
\text { transaksi merupakan bagian } \\
\text { dari laporan keuangan dan } \\
\text { transaksi kantor cabang } \\
\text { Syariah induk. . }\end{array}$ & $\begin{array}{l}\text { Memudahkan pengawasan } \\
\text { Bank Indonesia. } \\
\text { - Memudahkan pengaturan } \\
\text { kliring. }\end{array}$ & $\begin{array}{l}\text { - Kendala pelaporan one day } \\
\text { settlement bagi KCPS yang } \\
\text { jaraknya jauh atau sarana TI } \\
\text { yang belum memadai. }\end{array}$ \\
\hline $\begin{array}{l}\text { 6. Pembukaan KCPS tidak } \\
\text { dibatasi jangka waktu ter- } \\
\text { tentu. }\end{array}$ & $\begin{array}{l}\text { - Efisiensi biaya operasional } \\
\text { tanpa dibebani target } \\
\text { menjadi KCS. }\end{array}$ & $\begin{array}{l}\text { - KCPS akan tetap menjadi } \\
\text { jaringan kantor di bawah kantor } \\
\text { cabang. }\end{array}$ \\
\hline
\end{tabular}

Dari analisis di atas terlihat bahwa keunggulan utama dari KCPS adalah efisiensi ruangan dan tenaga kerja serta tanpa pembatasan waktu untuk menjadi Kantor Cabang Syariah. 


\section{Disain Unit Syariah dalam Struktur Organisasi Bank}

Disain Unit Syariah pada dasarnya merupakan model atau skema yang diadopsi dari skema "windows" atau SPTF pada jaringan perbankan di Malaysia. Penerapan Unit Syariah tidak mengadopsi sepenuhnya skema SPTF tetapi di lakukan modifikasi yang disesuaikan dengan kondisi perbankan dan masyarakat Indonesia.

\section{Mekanisme Operasional}

Sebagaimana halnya dengan KCPS, Unit Syariah dibentuk dengan tujuan untuk membentuk jaringan kantor bank Syariah yang murah, efisien, menjangkau wilayah yang luas, memiliki kredibilitas penerapan Syariah oleh masyarakat, serta menjalankan praktek bank yang sehat. Dalam upaya mencapai tujuan tersebut maka skema Unit Syariah akan berbeda dengan skema SPTF Malaysia. Unit Syariah dirancang memiliki persyaratan sebagai berikut:

1. Mendirikan Unit Usaha Syariah (UUS) di kantor pusat Bank sebagai kantor induk dari Unit-Unit Syariah.

2. Merupakan unit tersendiri di dalam kantor cabang dan atau kantor cabang pembantu konvensional dan secara struktur organisasi berada dalam tanggungjawab kantor cabang atau kantor cabang pembantu konvensional dimana Unit Syariah bertempat;

3. Memiliki ruangan atau counter tersendiri di dalam gedung kantor cabang/kantor cabang pembantu konvensional;

4. Memiliki pegawai tersendiri;

5. Kegiatan usaha meliputi kegiatan penghimpunan dana (funding), penyaluran dana (financing) dan jasa perbankan lainnya (service);

6. Laporan keuangan dan transaksi merupakan bagian dari laporan keuangan dan transaksi kantor cabang konvensional;

7. Menyusun pembukuan dan laporan keuangan yang terpisah dari pembukuan dan laporan keuangan kantor cabang atau kantor cabang pembantu konvensional.

Struktur organisasi Unit Syariah pada dasarnya akan terkait dengan Unit Usaha Syariah (UUS) sebagai kantor induk yang bertempat di kantor pusat Bank. UUS bertugas mengatur dan mengawasi seluruh kegiatan Unit-Unit Syariah, melaksanakan fungsi treasury dalam rangka pengelolaan dan penempatan dana yang bersumber dari Unit-Unit Syariah, 
menyusun laporan keuangan konsolidasi dari seluruh Unit-Unit Syariah, melaksanakan tugas penatausahaan laporan keuangan Unit-Unit Syariah. bentuk dasar Unit Syariah bertempat di alamat KC Konvensional. Struktur organisasi sebagai berikut:

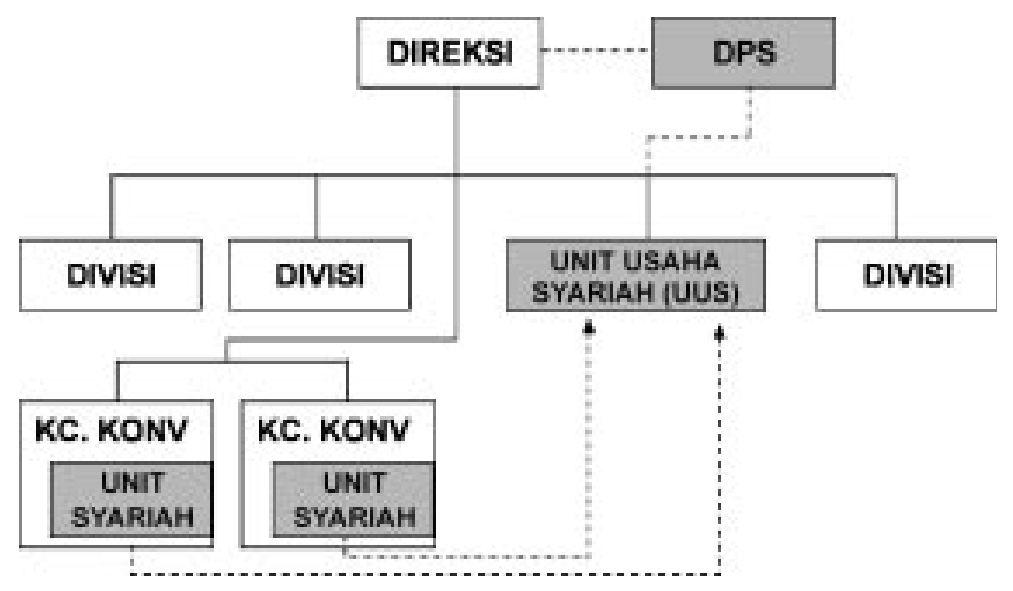

\section{Analisis Pros dan Cons}

Dengan memperhatikan disain Unit Syariah tersebut maka analisa pros dan cons yang muncul adalah sebagai berikut:

\begin{tabular}{|c|c|c|}
\hline Disain & Pros & Cons \\
\hline $\begin{array}{l}\text { 1. UNIT SYARIAH yang ber- } \\
\text { lokasi di kantor cabang } \\
\text { konvensional. }\end{array}$ & $\begin{array}{l}\text { Terdapat proses pembe- } \\
\text { lajaran dari KC/KCK un- } \\
\text { tuk secara bertahap men- } \\
\text { jadi KCS. }\end{array}$ & $\begin{array}{l}\text { - Kemungkinan adanya resistensi } \\
\text { atau keengganan dari pimpinan } \\
\text { KCK untuk mengembangan } \\
\text { US; }\end{array}$ \\
\hline $\begin{array}{l}\text { 2. Sebagai bagian dari kantor } \\
\text { cabang konvensional induk. }\end{array}$ & - Efisiensi biaya operasional. & $\begin{array}{l}\text { - Biaya lebih mahal untuk } \\
\text { bangun gedung atau sewa. }\end{array}$ \\
\hline 3. Memiliki pegawai tersendiri; & $\begin{array}{l}\text { - Kegiatan usaha menjadi } \\
\text { leboh konsentrasi } \\
\text { - Meningkatkan kredibilitas } \\
\text { penerapan Syariah. }\end{array}$ & $\begin{array}{l}\text { - Memerlukan ekstra biaya gaji } \\
\text { dan pelatihan. }\end{array}$ \\
\hline $\begin{array}{l}\text { 4. Kegiatan usaha meliputi } \\
\text { kegiatan penghimpunan } \\
\text { dana (funding), penyaluran } \\
\text { dana (financing) dan jasa } \\
\text { perbankan lainnya (service). }\end{array}$ & $\begin{array}{l}\text { Menyediakan pelayanan } \\
\text { perbankan Syariah yang } \\
\text { lengkap. } \\
\text { - Mendukung percepatan } \\
\text { penyelenggaraan sistem }\end{array}$ & $\begin{array}{l}\text { - Ekstra pengawasan internal } \\
\text { KCS; } \\
\text { - Ekstra pengawasan bank } \\
\text { sentral; }\end{array}$ \\
\hline
\end{tabular}




\begin{tabular}{|c|c|c|}
\hline & $\begin{array}{l}\text { perbankan Syariah yang } \\
\text { luas. }\end{array}$ & $\begin{array}{l}\text { - Masih terdapat kendala wila- } \\
\text { yah kliring }\end{array}$ \\
\hline $\begin{array}{l}\text { 5. Laporan keuangan dan } \\
\text { transaksi merupakan ba- } \\
\text { gian dari laporan keuangan } \\
\text { dan transaksi kantor cabang } \\
\text { Syariah induk. }\end{array}$ & $\begin{array}{l}\text { - Memudahkan pengawasan } \\
\text { Bank Indonesia. } \\
\text { - Memudahkan pengaturan } \\
\text { wilayah kliring. }\end{array}$ & $\begin{array}{l}\text { - Kendala pelaporan one day } \\
\text { settlement bagi UNIT SYARIAH } \\
\text { yang jaraknya jauh atau sarana } \\
\text { TI yang belum memadai. }\end{array}$ \\
\hline $\begin{array}{l}\text { 6. Perizinan kantor dan ke- } \\
\text { pesertaan kliring sesuai } \\
\text { dengan wilayah kerja Bank } \\
\text { Indonesia. }\end{array}$ & $\begin{array}{l}\text { - Memudahkan pengaturan } \\
\text { perizinan BI; } \\
\text { - Memudahkan pengaturan } \\
\text { kliring tanpa perubahan } \\
\text { ketentuan BI; }\end{array}$ & - Membatasi perluasan UNIT \\
\hline
\end{tabular}

Dengan memperhatikan analisis pros dan cons tersebut maka operasional Unit Syariah seharusnya memenuhi persyaratan dasar yang lebih menunjang aspek pros, sehingga nantinya dalam menyusun ketentuan Bank Indonesia dapat diaplikasikan tanpa mengalami banyak perubahan-perubahan yang prinsipil dalam peraturan yang diterbitkan oleh satuan kerja Bank Indonesia lainnya atau banyak mengubah tatanan ketentuan yang ada. Adapun aspek operasional yang paling aplikatif dan memberikan optimalisasi manfaat adalah:

- Unit Syariah beralamat di kantor cabang konvensional atau kantor cabang pembantu.

- Kegiatan usaha Unit Syariah merupakan bagian dari kegiatan usaha Kantor Cabang atau Kantor Cabang Pembantu konvensional yang berfungsi sebagai kantor induknya.

- Unit Syariah semata-mata hanya menyediakan produk dan pelayanan jasa bank Syariah yang sesuai dengan prinsip Syariah yang mencakup penghimpunan dana (funding), penyaluran dana (financing) dan pemberian jasa keuangan (service).

- Pembukuan dari kegiatan usaha Syariah dilakukan secara terpisah dari kegiatan kantor cabang atau kantor cabang pembantu bank konvensional.

- Pembukaan Unit Syariah oleh KCK dilakukan dengan tetap memperhatikan aspek keikutsertaan kliring;

- Dalam organisasi kantor pusat bank ditempatkan Dewan Pengawas Syariah (DPS) yang bertugas mengawasi kegiatan Unit Syariah agar sesuai dengan prinsip Syariah.

- Dalam organisasi kantor pusat bank dibentuk Unit Usaha Syariah yaitu satuan kerja setingkat dibawah direksi bank yang mengawasi dan menatausahakan kegiatan KCK/ KCP yang memiliki Unit Syariah. 


\section{Unit Syariah Merupakan Masa Transisi}

Tujuan akhir pembukaan Unit Syariah adalah terbentuknya kantor cabang Syariah. Dengan demikian dalam perencanaannya kegiatan Unit Syariah merupakan kegiatan yang bersifat sementara waktu dan selanjutnya diarahkan kepada pembentukan kantor cabang Syariah. Jangka waktu pembentukan Unit Syariah menjadi kantor cabang Syariah harus ditentukan dalam jangka waktu yang tidak terlalu lama namun tidak pula terlalu singkat. Jangka waktu yang ideal adalah jangka waktu yang memungkinkan Bank merencanakan kegiatan usaha Unit Syariah untuk berkembang dengan jumlah aset dan kecukupan modal yang memadai. Dilain pihak jangka waktu yang terlalu lama dapat menjadi moral hazard bagi Bank untuk memanfaatkan "windows" sistem dalam mengumpulkan dana masyarakat yang relatif murah tanpa adanya keinginan yang serius dari manajemen untuk membuka pelayanan kantor cabang Syariah. Berdasarkan pengalaman empiris perbankan diperlukan periode waktu antara 2 s.d. 6 tahun suatu kantor cabang berkembang mencapai break event point, menjadi kantor cabang yang stabil, serta menguntungkan. Dengan pengalaman empiris tersebut maka jangka waktu maksimum 3 s.d. 5 tahun merupakan jangka waktu rata-rata yang cukup memadai untuk ditetapkan sebagai jangka waktu transisi dan persiapan dari Unit Syariah menjadi kantor cabang Syariah. Persiapan yang dilakukan oleh Unit Syariah bank untuk menjadi kantor cabang Syariah adalah tambahan modal kerja minimum untuk KCS. Tambahan modal minimum merupakan pemenuhan modal KCS sesuai ketentuan Bank Indonesia yang berlaku dan persiapan sumber daya insani untuk KCS . Penambahan pegawai diperlukan karena ruang lingkup kegiatan usaha KCS menjadi lebih besar.

Dengan adanya perubahan Unit Syariah menjadi KCS maka struktur organisasi berubah menjadi sebagai berikut:

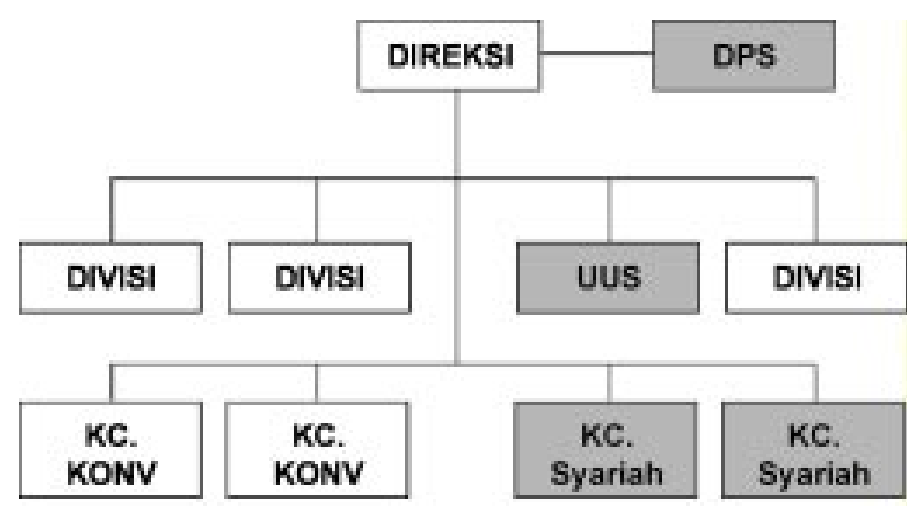




\section{Persyaratan Pembukaan}

\section{Persyaratan Minimum}

- Persyaratan minimum bagi Bank pembuka Unit Syariah akan sangat terkait dengan kemampuan keuangan dan kondisi bank induk konvensional. Kondisi Bank pembuka harus memiliki kondisi permodalan dan manajemen yang baik karena kondisi permodalan dan manajemen Bank yang baik akan menghasilkan kinerja usaha bank Syariah yang baik pula sebagaimana diperlihatkan oleh Islamic Banking Unit (IBU) RHB Bank dan May Bank Malaysia. Dengan demikian perbankan konvensional yang berminat untuk membuka Unit Syariah harus memenuhi persyaratan yang berfokus kepada aspek komitmen, kemampuan, dan kehati-hatian usaha. Terdapat kesulitan untuk mengetahui komitmen manajemen dalam menjalankan kegiatan usaha bank berdasarkan prinsip Syariah secara sehat dan patuh Syariah (prudent banking and sharia compliance). Namun demikian alternatif yang dapat digunakan untuk mengetahui komitmen manajemen adalah melalui wawancara dalam rangka fit and proper test, proses mempersiapkan sumber daya manusia, serta adendum perubahan anggaran dasar bank yang menyatakan bahwa bank dapat melakukan kegiatan usaha Syariah. Perubahan anggaran dasar memerlukan persetujuan Rapat Umum Pemegang Saham sehingga menimbulkan pula komitmen dari pemilik bank dalam menjalankan kegiatan usaha bank Syariah. Kondisi bank merupakan prasyarat yang sangat penting untuk menjalankan kegiatan usaha bank Syariah. Kondisi keuangan dan kesehatan bank terutama ditujukan kepada kondisi permodalan, kualitas aset bank, dan rentabilitas. Adanya bank yang kurang sehat dan kemudian melakukan kegiatan usaha bank Syariah dapat menimbulkan image yang kurang baik bahwa kegiatan usaha bank Syariah hanya merupakan pengalihan kegiatan usaha bank-bank yang bermasalah. Dengan demikian strategi entry policy bagi kegiatan usaha bank Syariah sangat jelas bahwa hanya bankbank yang sehat atau sekurang-kurangnya cukup sehat dapat melakukan kegiatan usaha Syariah. Pengukuran aspek keuangan di Malaysia berpedoman kepada unsur rentabilitas dan likuiditas dalam CAMEL system. Mengingat saat ini belum terdapat standar umum yang mengatur pengukuran rentabilitas dan likuiditas bank Syariah, maka standar umum BIS untuk sementara waktu dapat digunakan. Aspek penting lain adalah tidak terdapat permasalahan bank yang bersifat struktural dimana untuk menilai permasalahan bank yang struktural dapat mempergunakan standar umum yang berlaku seperti: perselisihan intern, praktek bank dalam bank, dalam status diskors peserta kliring. Pemenuhan rasio modal menjadi prasyarat yang fundamental, pemenuhan rasio modal secara internasional adalah $8 \%$ dari modal inti dan modal pelengkap. Rasio ini dalam jangka panjang harus disesuaikan dengan pengaturan permodalan khusus bagi bank 
Syariah dengan memperhatikan komponen-komponen permodalan yang sesuai dengan bank Syariah. Aspek lain adalah mempersiapkan modal kerja untuk keperluan operasional Unit Syariah.Modal kerja yang dibutuhkan tidak sebesar pendirian KCS. Modal yang diperlukan adalah untuk sewa ruangan, pengadaan peralatan (komputer, telepon, faksilimili dll), biaya pegawai, dan biaya administratif lainnya. Tak kalah pentingnya adalah mempersiapkan Sumber Daya Insani (SDI). SDI yang diperlukan untuk setiap Unit Syariah menerapkan prinsip penggunaan efisiensi dan keamanan SDI. Untuk mengelola Unit Syariah maka SDI yang diperlukan adalah pegawai atau staf Unit Syariah yang telah mengikuti pelatihan atau berpengalaman melakukan kegiatan usaha bank Syariah dan menyelenggarakan pelatihan kegiatan usaha bank Syariah bagi pegawai atau staf yang belum pernah pelatihan atau pengalaman. Untuk operasional awal hanya diperlukan sekurang-kurannya 3 orang (1 pimpinan merangkap analis pembiayaan dan pembukuan; 1 teller yang menangani penyetoran dan penarikan dana tabungan, deposito, dan giro; 1 teller yang menangani jasa perbankan lainnya dan administrasi surat). Hal yang terakhir dan juga sangat vital adalah aspek keamanan fisik dan dana. Unit Syariah terletak di dalam lokasi kantor cabang konvensional yang telah memiliki fasilitas satuan pengamanan, sehingga untuk Unit Syariah tidak diperlukan tenaga satuan pengamanan. Unit Syariah tidak perlu membentuk khasanah yang besar tetapi cukup lemari besi yang memiliki kode pengamananan karena Unit Syariah dapat melakukan kerjasama dalam penitipan kas dengan kantor cabang konvensional setempat.

\section{Pengajuan Permohonan Pembukaan Unit Syariah}

Bank mengajukan proposal yang berisikan pokok-pokok sebagai berikut:

- Alamat kantor bank;

Alamat Unit Syariah harus ditentukan secara jelas dengan mencantumkan identitas kantor "Unit Syariah" di tempat Unit Syariah beroperasi.

- Hasil analisis peluang pasar dan potensi ekonomi;

Merupakan analisa lengkap namun singkat yang dilakukan oleh bank pemohon untuk meneliti peluang pasar nasabah yang memerlukan atau tertarik terhadap pelayanan jasa bank Syariah, sedangkan potensi ekonomi merupakan analisa makro terhadap kondisi sektor-sektor usaha yang ada dan prospek pengembangan sektor-sektor usaha dalam jangka waktu proyeksi minimal 1 tahun kedepan yang menunjang pengembangan Unit Syariah. 
- Rencana kegiatan usaha;

Merupakan rencana Unit Syariah minimal untuk 1 tahun kedepan dalam target penghimpunan dana, penyaluran dana, dan kegiatan pelayanan jasa bank. Dalam rencana kegiatan usaha ini termasuk rencana phasing out atau rencana pengalihan secara bertahap kegiatan usaha konvensional menjadi kegiatan usaha Syariah dalam periode waktu yang ditetapkan untuk menjadi KCS.

- Jenis penghimpunan dana dan pembiayaan;

Jenis titipan, investasi, atau investasi terbatas yang disediakan oleh Unit Syariah seperti dalam bentuk giro, tabungan, deposito atau bentuk investasi dana dari masyarakat lainnya serta jenis pembiayaan yang disediakan oleh Unit Syariah.

- Sarana dan SDI;

Infrastruktur dan sumber daya manusia termasuk program pelatihan pegawai untuk Unit Syariah;

- Aspek akuntansi;

Penerapan sistem akuntansi berdasarkan standar yang ditetapkan secara nasional dan Bank Indonesia.

- Kegiatan administrasi;

Sistem dan prosedur (Sisdur) sederhana untuk proses penghimpunan dana, penyaluran dana, pembukuan, dan dokumentasi;

- Bisnis terkait; seperti takaful dan lainnya.

\section{Perizinan Bank Indonesia}

Mengingat Unit Syariah ditujukan untuk mendukung pengembangan jaringan kantor yang efisien dan ekonomis maka bank yang mengajukan Unit Syariah meminta izin usaha kepada Bank Indonesia dengan memperhatikan aspek kemudahan tetapi tetap menjaga praktek perbankan yang sehat. Dengan demikian untuk bank yang telah memiliki UUS maka perizinan Unit Syariah langsung diberikan dalam bentuk izin usaha. Sedangkan untuk bank yang belum memiliki UUS maka permohonan izin dilakukan dengan sekaligus mengajukan pembentukan UUS melalui proses izin prinsip dan izin usaha. 


\section{Membentuk Unit Usaha Syariah}

Bagi bank yang belum memiliki UUS maka wajib mengajukan permohonan pembukaan UUS terlebih dahulu dengan mengikuti persyaratan pembukaan UUS. Secara makro ekonomi pembentukan UUS akan membentuk central unit dan centre of Islamic activities bagi seluruh kegiatan perbankan Syariah dalam payung entitas kegiatan perbankan konvensional. Central unit ini berfungsi pula sebagai centre of capital dengan pemupukan modal yang terpisah dan terpusat serta sebagai internal Islamic business supervision atau pengawasan terpusat dari seluruh kegiatan usaha berdasarkan Syariah oleh bank konvensional.

\section{Modal kerja}

Modal kerja Unit Syariah dapat berupa kas yang secara minimal ditentukan dengan suatu peraturan Bank Indonesia dan non-kas tanpa batasan minimal yang mencukupi untuk pengadaan sarana kantor, biaya tenaga kerja, biaya administrasi, dan biaya lainnya.

Adanya modal kerja yang terpisah pada dasarnya akan memperkuat pemupukan modal dari UUS, kantor-kantor cabang Syariah, dan Unit-Unit Syariah sehingga dapat memenuhi aspek syariah pada prinsip pemisahan modal dan aspek praktek praktek perbankan yang sehat dengan penyediaan modal untuk menampung risiko kerugian.

\section{Informasi Produk Bank Syariah}

Kegiatan usaha bank Syariah memiliki karakter produk dan jasa yang berbeda dengan karakter produk dan jasa bank konvensional. Dengan demikian perlu diberikan informasi yang jelas kepada masyarakat mengenai produk dan jasa bank Syariah yang ditawarkan oleh kantor bank pembuka Unit Syariah. Informasi yang jelas tersebut berupa papan nama "Unit Syariah" disertai daftar produk serta jasa berdasarkan prinsip Syariah.

\section{Sistem Informasi dan Dokumentasi}

Sistem informasi dan dokumentasi Unit Syariah dilakukan berdasarkan kepada prinsip pemisahan pembukuan dan pemisahan pengarsipan dari kegiatan usaha atau transaksi konvensional. Adanya pemisahan pembukuan dan dokumentasi/arsip selain memenuhi persyaratan Syariah juga memudahkan penatausahaan dan verifikasi oleh manajemen bank dan eksternal auditor.

\section{Dewan Pengawas Syariah}

Sesuai dengan UU Perbankan kantor bank konvensional yang melakukan kegiatan 
usaha bank Syariah harus membentuk Dewan Pengawas Syariah (DPS). Tugas DPS adalah mengawasi kegiatan usaha bank pembuka Unit Syariah agar kegiatan dan produk kantor bank Unit Syariah sesuai dengan prinsip Syariah.

\section{Pelaksanaan Kliring, Sistem Akuntansi dan Pelaporan}

Dengan kedudukan UnitSyariah yang setara dengan kantor cabang pembantu dalam kegiatan usaha penghimpunan dana, penyaluran dana, dan pelayanan jasa maka pelaksanaan kliring bagi Unit Syariah merupakan bagian yang penting dalam rangka menunjang kelancaran bisnis para nasabah. Dikaitkan dengan konsep Unit Syariah yang bertujuan untuk menjangkau wilayah yang luas maka pelaksanaan kliring akan terkait dengan ketentuan dan mekanisme yang sudah berlaku di Bank Indonesia yaitu wilayah kerja dan wilayah kliring. Dengan status Unit Syariah sebagai bagian dari KC/KCP konvensional, maka pelaksanaan kliring secara langsung dapat dilakukan melalui rekening $\mathrm{KC} / \mathrm{KCP}$ konvensional. Dalam upaya menerapkan prinsip pemisahan pembukuan maka pada akhir hari penyelesaian kliring antara Unit Syariah dengan KC/KCP konvensional dilakukan secara internal. Dalam hal Unit Syariah mengalami saldo negatif maka penyelesaian tagihan dilakukan KC/KCP konvensional kepada Unit Usaha Syariah di Kantor Pusat Bank.

Sistem akuntansi bank pembuka Unit Syariah secara konsolidasi menggunakan standar akuntansi perbankan umum sepanjang tidak bertentangan dengan prinsip Syariah. Apabila standar akuntansi Syariah sudah ditetapkan maka diberlakukan standar akuntansi Syariah, dan kegiatan usaha Syariah tersebut disajikan dalam laporan tersendiri (notes). Kerangka dasar standar akuntansi syariah berlaku kerangka dasar akuntansi yang telah berlaku secara universal sepanjang tidak bertentangan dengan prinsip Syariah dan harus mampu mencatat, mengakui, menyajikan, dan melaporkan seluruh transaksi keuangan bank syariah yang melakukan fungsi manajer investasi yang dapat mengelola investasi atas dana nasabah, investor yang dapat menginvestasikan dana yang dimiliki maupun dana nasabah, penyedia jasa keuangan dan lalu lintas pembayaran, dan pelaksana kegiatan keuangan sosial dalam bentuk pemungut atau pengelola dana zakat, infaq, shadaqah serta dana sosial lainnya (qardhul hasan).

Pelaporan keuangan bank pembuka Unit Syariah dilakukan dengan menggunakan basis laporan berkala kantor cabang Syariah kepada Bank Indonesia sesuai dengan ketentuan laporan berkala yang berlaku. Laporan keuangan berkala kantor cabang Syariah antara lain yaitu laporan bulanan, laporan triwulanan, laporan tahunan, serta laporanlaporan lainnya. Pelaporan berkala oleh KCPS pada dasarnya tidak mengalami permasalahan yang mendasar karena secara organisasi KCPS berada dibawah naungan 
KCS sehingga laporan berkala dilakukan berdasarkan rekapitulasi yang dilakukan oleh KCS. Sedangkan untuk US mengingat kedudukan US berada didalam dan bertanggungjawab kepada KCK maka laporan berkala yang dilakukan oleh US ikut kepada laporan berkala yang dilakukan oleh KCK dimana US berada.

\section{Pengawasan Bank Indonesia}

Sebagaimana halnya dengan lembaga perbankan pada umumnya, maka Unit Syariah tetap memiliki fungsi mendasar lembaga bank yaitu sebagai Unit yang mengelola dana milik masyarakat.

Berkaitan dengan pengelolaan dana masyarakat tersebut maka mekanisme pengawasan secara on-site maupun off-site dilaksanakan oleh Bank Indonesia dengan memperhatikan karakteristik produk dan jasa bank Syariah. Dalam pengawasan ini Bank Indonesia melakukan koordinasi dengan DPS bank atau dengan Dewan Syariah Nasional (DSN) untuk memastikan kepatuhan aspek Syariah.

Hal yang penting dalam pengawasan Bank Indonesia adalah adanya kegiatan pengawasan yang mendukung terwujudnya customer education dalam kegiatan Unit Syariah.

Hal-hal yang terkait dengan customer education adalah perilaku nasabah yang memanfaatkan atau mengambil keuntungan dari perbedaan sistem yang ada di KC konvensional dan Unit Syariah misalnya nasabah menyimpan dana di KC konvensional dan mengajukan pembiayaan kepada Unit Syariah, atau nasabah mengajukan pembiayaan ke Unit Syariah dengan jaminan cash collateral simpanan di KC konvensional.

Upaya menciptakan customer education alternatif solusi adalah Aspek pengaturan dengan menentukan dalam pedoman pendirian dan kegiatan usaha Unit Syariah, ketentuan bahwa nasabah yang mengajukan pembiayaan di Unit Syariah harus membuka rekening giro, tabungan atau deposito dan melarang menjaminkan cash collateral simpanan di KC konvensional. Aspek pros yang muncul adalah menerapkan konsistensi prinsip Syariah dan menjaga kredibilitas Unit Syariah. Sedangkan aspek cons adalah membatasi mekanisme pasar dan kebebasan nasabah.

Alternatif solusi lainnya adalah Aspek mekanisme pasar yaitu dalam kasus nasabah menyimpan dana di KC konvensional dan mengajukan pembiayaan kepada Unit Syariah maka menyerahkan sikap nasabah kepada mekanisme pasar. Pros: mendukung prinsip market driven dengan menerapkan mekanisme pasar dan kebebasan pada nasabah namun cons dapat mengurangi kredibilitas dalam konsistensi penerapan Syariah. 


\section{Kesimpulan}

Berdasarkan kajian yang dilakukan di atas maka dapat kami simpulkan hal-hal sebagai berikut:

1. Denganjumlah kantor bank Syariah yang ada dan berkumpula di kota-kota besar tertentu maka kebutuhan masyarakat terhadap pelayanan jasa perbankan Syariah belum dapat dipenuhi secara memadai.

2. Berdasarkan penelitian pembukaan jaringan kantor bank Syariah sebagai kegiatan bisnis perbankan memiliki potensi yang tinggi pada hampir seluruh wilayah Indonesia khususnya daerah Pulau Jawa.

3. Ketentuan Bank Indonesia yang ada belum mengatur pembukaan kantor bank Syariah yang relatif mudah, mampu berkembang secara cepat, dan dapat mencapai pelosokpelosok daerah.

4. Pembentukan skema kantor cabang pembantu Syariah (KCPS) dan Unit Syariah (US) memiliki keunggulan yang dapat mengakomodasi kendala pengembangan kantor bank Syariah yaitu perizinan lebih sederhana, biaya lebih efisien karena beralamat atau menumpang pada kantor bank konvensional yang sudah ada, serta mudah dilakukan pengawasan karena diharuskan memisahkan pembukuan kegiatan usaha Syariah terhadap kegiatan konvensional.

5. Dalam upaya mendirikan KCPS dan US yang sehat dan melaksanakan praktek perbankan yang sehat maka untuk pendirian KCPS dan US, manajemen bank harus menyediakan modal kerja minimum yang ditetapkan secara memadai untuk kegiatan operasional KCPS dan US.

6. Dalam upaya memberikan kegiatan usaha yang mencakup penghimpunan dana, penyaluran dana, serta pemberian jasa maka KCPS dan US harus diberikan wewenang keikutsertaan kliring dalam suatu wilayah kerja Bank Indonesia.

7. Kegiatan usaha Unit Syariah dibatasi waktu tertentu antara 3 s.d. 5 tahun harus menjadi Kantor Cabang Syariah dalam upaya menegakkan komitmen manajemen bank dalam pengembangan Unit Syariah.

8. Pengaturan KCPS dan US harus dilakukan dalam bentuk Peraturan Bank Indonesia sehingga memberikan kepastian hukum yang kuat kepada para pihak yang berkepentingan.

9. Pengaturan US harus benar-benar ketat sehingga hanya memungkinkan bagi bank konvensional yang telah memiliki perencanaan yang matang dan keseriusan untuk 
menggunakan sarana US sebagai masa persiapan menjadi Kantor Cabang Syariah.

10. Penerapan public/customers education dalam produk bank Syariah menjadi faktor yang penting untuk menutupi celah kelemahan ketentuan dalam pelayanan jasa bank Syariah terhadap nasabah yang memanfaatkan produk yang tersedia baik bank Syariah dan bank konvensional.

\section{REFERENSI}

1. Undang-Undang No.7 Tahun 1992 tentang Perbankan sebagaimana telah diubah dengan Undang-undang No.10 Tahun 1998.

2. Skim Perbankan Tanpa Faedah, Bank Negara Malaysia, 1993

3. Publication Booklet RHB Islamic Banking Unit 2001

4. Bank Syariah Bagi Bankir Dan Praktisi Keuangan, Muhammad Syafi'i Antonio \& Bank Indonesia, Tazkia Institute, 1999. 